\title{
Solution Processed Silver Nanoparticles in Dye-Sensitized Solar Cells
}

\author{
Marko Berginc, Urša Opara Krašovec, and Marko Topič \\ University of Ljubljana, Faculty of Electrical Engineering, Tržaška 25, 1000 Ljubljana, Slovenia \\ Correspondence should be addressed to Marko Berginc; marko.berginc@fe.uni-lj.si
}

Received 7 November 2013; Accepted 15 January 2014; Published 24 February 2014

Academic Editor: Jianping Xie

Copyright ( 2014 Marko Berginc et al. This is an open access article distributed under the Creative Commons Attribution License, which permits unrestricted use, distribution, and reproduction in any medium, provided the original work is properly cited.

\begin{abstract}
A plasmonic effect of silver nanoparticles (Ag NPs) in dye-sensitized solar cells (DSSCs) is studied. The solutions of silver nitrate in isopropanol, ethylene glycol, or in $\mathrm{TiO}_{2}$ sol were examined as possible precursors for Ag NPs formation. The solutions were dipcoated on the top of the porous $\mathrm{TiO}_{2}$ layer. The results of optical measurements confirmed the formation of Ag NPs throughout the porous $\mathrm{TiO}_{2}$ layer after the heat treatment of the layers above $100^{\circ} \mathrm{C}$. Heat treatment at $220^{\circ} \mathrm{C}$ was found to be optimal regarding the formation of the Ag NPs. The porous $\mathrm{TiO}_{2}$ layers with Ag NPs have been evaluated also in DSSC by measuring current-voltage characteristics and the external quantum efficiency of the cells. In addition, the amount of adsorbed dye has been determined to prove the plasmonic effect in the cells. The $I-V$ characterization of the DSSCs revealed an increase of the short circuit current in the presence of Ag NPs although the amount of the attached dye molecules decreased. These results confirm that the performance enhancement is related to the plasmonic effect. However, neither a thin sol-gel $\mathrm{TiO}_{2}$ layer nor poly(4-vinylpyridine) shells provide effective protection for the long term stability of the Ag NPs against the corrosion of $\mathrm{I}_{3}{ }^{-} / \mathrm{I}^{-}$based electrolyte.
\end{abstract}

\section{Introduction}

In the last decade the processes and new materials for dye-sensitized solar cells (DSSCs) have been extensively researched in order to enhance the performance and the stability of the cells [1-4]. In order to broaden and/or increase the spectral sensitivity of the solar cell several concepts have been considered, for example, the quest for new sensitizers [5-7] or cosensitizers [8-11], different approaches for engineering active layer/electrolyte interface [12], optimizing the thickness of the active layer, or increasing the concentration of the attached dye molecules [13-15]. Absorption has also been improved by increasing the optical path using larger scattering particles or voids in the active layer [14, 16-18]. Furthermore, an undyed layer placed on top of the active layer $[13,14,19,20]$ or a mirror-like Pt counter electrode [21-30] was studied as an internal back reflector. In addition, different materials have also been proposed as external back reflectors placed at the rear side of the DSSCs [31, 32].

In recent years a surface plasmon resonance using metal nanoparticles (NPs) has also attracted much attention and has been studied for various solar cell technologies [33-37]. The surface plasmon resonance is a light induced coherent oscillation of conduction band electrons on the surface of the metal NPs. The wavelength of resonance peak due to the presence of plasmonic particles greatly depends on factors such as size, shape, and dielectric environment. Two types of enhanced absorption are possible: (1) near-field: a strong electromagnetic field in the vicinity of the NPs around the plasmonic resonance wavelengths greatly enhances the absorption in the active layer and (2) far-field enhancement of the light absorption in the photoactive layer due to the scattering effect.

In the last few years a concept of surface plasmon resonance has been introduced to the dye-sensitized solar cells employing noble metals, mostly Ag [38-48] or Au NPs $[42,47,49-56]$. The scattering, that is, far-field enhancement (arrows in Figure 1) is generally already present in DSSC due to the strong scattering of the porous $\mathrm{TiO}_{2}$ layer. Therefore, the researchers focused mostly on the near-field plasmonic (dashed circles in Figure 1) where the absorbing dye should be close to the NPs and the electromagnetic field around 


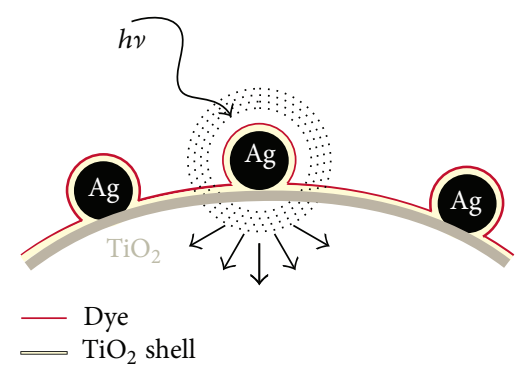

FIGURE 1: Near-field (dashed circles) and far-field effect (arrows) in the DSSC.

NPs significantly enhances the absorption of the dye and consequently increases the $J_{\mathrm{SC}}$.

The proof of the concept was firstly presented on two simplified flat structures. The first one contained dyed $\mathrm{Ag}$ NPs on compact $\mathrm{TiO}_{2}$ layer placed over the front transparent conductive oxide (TCO) $[38,41]$. In the studies, a less harmful $\mathrm{Co}^{2+/ 3+}$ based redox electrolyte was used in order to preserve unprotected Ag NPs. The second structure contained Ag NPs deposited on the front TCO that were protected with a thin compact $\mathrm{TiO}_{2}$ layer, varying in thickness between 2 and $9 \mathrm{~nm}$, covered with a monolayer of dye molecules [39, 40]. The results confirmed that the electromagnetic field related to the near-field plasmonic effect decreases with a power of two by increasing the thickness of the $\mathrm{TiO}_{2}$ shell around NPs, that is, by increasing the distance from the dye molecules and NPs $[39,40]$. If the shell was thicker than $2 \mathrm{~nm}$ the plasmonic effect was hindered. On the other hand, the shell should protect the NPs from aggressive electrolyte; therefore the shell should not be too thin either $[43,55,57,58]$. The study showed that to fully protect the Ag NPs at least $7.7 \mathrm{~nm}$ thick compact crystalline $\mathrm{TiO}_{2}$ layer is needed [39]. The near-field plasmonic enhancement in DSSC was confirmed but the performance of the cells was very low $(>0.05 \%)$ due to the very thin active layers used in this study.

So far several different locations of NPs and deposition techniques have been proposed to prepare DSSC with plasmonic enhancement.

(i) Location 1: NPs deposited on the front TCO by soaking the front TCO in suspensions containing NPs [49] or by sputtering the NPs [44].

(ii) Location 2: the NPs are formed throughout porous $\mathrm{TiO}_{2}$ layer.

(a) One-step preparation of the active layer with NPs: the metal (core shell) NPs precursors are mixed in $\mathrm{TiO}_{2}$ paste and the (core shell) NPs are formed after annealing process [43, 48, 50, 53-56].

(b) Two-step preparation of the active layer with NPs: undyed/dyed porous $\mathrm{TiO}_{2}$ layers are (i) immersed into or (ii) spin-coated by a metal salt solution or a solution containing core shell NPs and after additional treatment (e.g., drying, heat treatment, photocatalitic reduction under UV illumination, etc.), the (core shell) NPs are formed [42, 45, 51, 52, 55, 58].

(iii) Location 3: NPs located at a certain position within the porous $\mathrm{TiO}_{2}$ layer.

A thin metal layer is sputtered on the porous $\mathrm{TiO}_{2}$ layer which created NPs after heat treatment. Afterwards, additional porous $\mathrm{TiO}_{2}$ overlayers have been deposited [46].

(iv) Location 4: NPs located on the top of the porous $\mathrm{TiO}_{2}$. A thin metal layer is sputtered at the back side of the dyed/undyed $\mathrm{TiO}_{2}$ layer which created NPs at the rear side after heat treatment [44, 46, 47].

The researchers confirmed a significant effect of the NPs location, concentration, and size on the performance enhancement. Therefore, they have to be carefully optimized according to the DSSCs structures (thickness of the active layer, electrolyte, dye, etc.) in order to achieve the highest plasmonic enhancement. Generally, the highest enhancement is found when the NPs are spread throughout the active layer $[42,53]$. Furthermore, larger NPs shift the plasmonic resonance toward longer wavelengths, but the magnitude of the shift strongly depends on the materials used for NPs and the dielectric environment (surrounding material), for example, the resonance peak of the Au NPs in a suspension shifts from $519 \mathrm{~nm}$ to $579 \mathrm{~nm}$, when the diameter of the NPs increases from 20 to $80 \mathrm{~nm}$ [49]. On the other hand, a parasitic absorption within NPs could significantly hamper the plasmonic effect $[45,59]$ if the NPs exceed optimal size or agglomeration takes place. The simulations showed that the absorption of metal nanoparticles could take up about 20$30 \%$ of the total absorption of DSSC at visible wavelengths even under the optimized conditions [59].

Some researchers studied the structures containing unprotected NPs $[44,46,47,49,54,56,58,59]$ but the long term stability remains questionable, since the $\mathrm{I}_{3}{ }^{-} / \mathrm{I}^{-}$ based electrolyte is very aggressive even to Au NPs [39, 52]. Additionally, the unprotected NPs could act as effective recombination centres [55]; therefore many research focused also on core/shell or even core/shell/shell NPs with Ag or $\mathrm{Au}$ cores and $\mathrm{TiO}_{2}[42,43,45,48,50,53], \mathrm{SiO}_{2}[50,53$, $55]$, or organic shells $[51,52]$. In addition to careful design regarding the location, concentration, and size of the NPs it has been stressed on that the shell should be pinhole free to ensure the protection against electrolyte, but on the other hand the shell should be as thin as possible to utilize the plasmonic effect [39, 40, 45, 52, 57] and to reduce parasitic absorption within a shell. A red shift in plasmonic resonance by increasing the thickness of the shell was also observed [39]. In addition to the plasmonic effect the NPs present in the cell structure could induce different effects influencing the solar cell parameters. The NPs with the $\mathrm{TiO}_{2}$ shell can upward shift the Fermi level of the $\mathrm{TiO}_{2}$, reduce the dark current, and increase the electron lifetime which all increase the $V_{\mathrm{OC}}$ $[43,53]$. Additionally, the NPs can simultaneously increase the internal surface available for dye loading which additionally increases the $J_{\mathrm{SC}}[45]$. Therefore, the performance 
enhancement due to the plasmonic effect should be always very carefully examined.

Many researchers significantly improved the conversion efficiency when NPs were incorporated (from 30\% up to $140 \%$, relatively) $[47,50,52,55,60]$, but high relative improvements were generally not obtained for the solar cells achieving state-of-the-art efficiency. Nevertheless, some researchers found remarkable improvements also in absolute terms. Dang et al. [42] found an improvement of the performance from 8.3 to $10.8 \%$ when $\mathrm{TiO}_{2} / \mathrm{Au} / \mathrm{TiO}_{2}$ core/shell/shell NPs were included throughout the active layer of the DSSC. Furthermore, Choi et al. [53] increased the efficiency of DSSC from 9.3\% to $10.2 \%$ after incorporating $\mathrm{Au} / \mathrm{SiO}_{2}$ core/shell NPs, while the $\eta$ increased only to $9.8 \%$ when the $\mathrm{TiO}_{2}$ shell was applied.

Herein, the DSSCs containing Ag NPs throughout the active layer are examined in Figure 2. Ethylene glycol and isopropanol were used to prepare silver nitrate solutions that have been used for the impregnation of the porous $\mathrm{TiO}_{2}$ layer. The formation of Ag NPs formed at five different temperatures was examined using optical measurements of the samples deposited on microscope glass. The optimal temperature determined to be $220^{\circ} \mathrm{C}$ was used for the preparation of the Ag NPs within porous $\mathrm{TiO}_{2}$ layers for DSSCs. The prepared $\mathrm{Ag}_{\text {ISO }}$ NPs were afterwards protected with either a thin $\mathrm{TiO}_{2}$ layer or organic shell based on poly(4vinylpyridine), PVP. In addition, the feasibility of the formation of $\mathrm{Ag} / \mathrm{TiO}_{2}$ core/shell NPs in a single step was studied by incorporation of the silver nitrate to the Ti sol.

The porous $\mathrm{TiO}_{2}$ layers with $\mathrm{Ag}$ NPs have been tested in the DSSC. To evaluate the plasmonic enhancement external quantum efficiency (EQE), current-voltage characteristics ( $I$ $V$ ) at standard test conditions and the amount of the adsorbed dye were measured and compared to our reference DSSCs without NPs. Finally, a stability of the Ag NPs against electrolyte in DSSCs is presented by remeasuring the $I-V$ characteristics of DSSCs three months after manufacturing and by exposing the $\mathrm{Ag}_{\mathrm{ISO}} / \mathrm{TiO}_{2}$ and $\mathrm{Ag}_{\mathrm{ISO}} / \mathrm{PVP}$ core shell NPs to $\mathrm{I}_{3}{ }^{-} / \mathrm{I}^{-}$redox electrolyte and measuring the difference in absorption.

\section{Experimental}

2.1. Preparation of the Active Layer. An optimized Pechini sol-gel $\mathrm{TiO}_{2}$ paste (based on P25, Degussa) [61] was applied to the glass substrate using a "doctor blading" technique. For optical measurements a microscope glass was used as substrate while a fluorine-doped $\mathrm{SnO}_{2}$ coated glass (TCO) with a sheet resistance of $8 \Omega$ /square was used for the DSSCs' substrate. After deposition, the $\mathrm{TiO}_{2}$ layers were sintered at $450^{\circ} \mathrm{C}$ for 1 hour.

Three different solutions containing Ag NPs precursors were studied. Solution $1\left(\mathrm{Ag}_{\text {ISO }}\right)$ was $0.004 \mathrm{M} \mathrm{AgNO}_{3}$ in isopropanol, solution $2\left(\mathrm{Ag}_{\mathrm{EG}}\right)$ was $0.004 \mathrm{M} \mathrm{AgNO}_{3}$ in ethylene glycol, and solution $3\left(\mathrm{Ag} / \mathrm{TiO}_{2}\right)$ was $\mathrm{Ag}_{\text {ISO }}$ mixed with $\mathrm{TiO}_{2}$ sol in a molar ration $0.4 \mathrm{M} / 0.004 \mathrm{M}$. The $\mathrm{TiO}_{2}$ sol was prepared by mixing the Titanium (IV) isopropoxide (Aldrich) with acetyl acetone (Fluka) in molar ratio 1:1.5

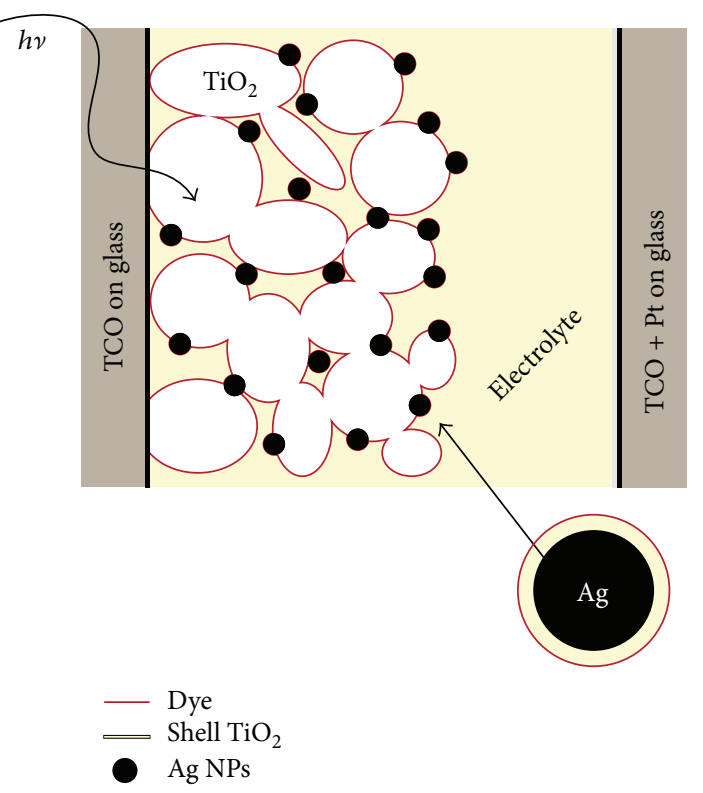

FIgURE 2: Cross section of DSSC with integrated $\mathrm{Ag} / \mathrm{TiO}_{2}$ core shell NPs in the active layer.

in isopropanol to obtain the sol with $0.4 \mathrm{M}$ of titanium. To deposit the Ag NPs on porous $\mathrm{TiO}_{2}$ layers the dip-coating method was used (speed $10 \mathrm{~cm} / \mathrm{min}$ ). The layers were heattreated for $1 \mathrm{~h}$ at different temperatures from 100 to $300^{\circ} \mathrm{C}$. After heat treatment the bare $\mathrm{Ag} \mathrm{NPs}\left(\mathrm{Ag}_{\mathrm{ISO}}\right.$ and $\left.\mathrm{Ag}_{\mathrm{EG}}\right)$ or $\mathrm{Ag} /$ $\mathrm{TiO}_{2}$ core/shell NPs within a porous $\mathrm{TiO}_{2}$ layer were formed $\left(\mathrm{Ag} / \mathrm{TiO}_{2}\right)$.

For the stability tests (Section 3.3) the bare $\mathrm{Ag}_{\text {ISO NPs }}$ were coated with either a thin $\mathrm{TiO}_{2}$ or PVP shell. To make a $\mathrm{TiO}_{2}$ shell the $\mathrm{Ag}-\mathrm{TiO}_{2}$ layers were additionally dipcoated using the $\mathrm{TiO}_{2}$ sol (speed $10 \mathrm{~cm} / \mathrm{min}$ ) and heat treated at $220^{\circ} \mathrm{C}$ for $1 \mathrm{~h}$. To form a PVP shell around $\mathrm{Ag}_{\text {ISO }}$ NPs we soaked the $\mathrm{Ag}-\mathrm{TiO}_{2}$ layers for $24 \mathrm{~h}$ into a solution containing $0.005 \mathrm{M}$ poly(4vinylpyridine) in acetonitrile.

2.2. DSSC Preparation. The $\mathrm{TiO}_{2}$ layers without/with Ag NPs have been immersed in an ethanol solution of a Ruthenium complex based dye ( $\operatorname{Ru}\left(2,2^{\prime} \text { bipyridyl- } 4,4^{\prime} \text { dicarboxylate }\right)_{2}$ $(\mathrm{NCS})_{2}$, Solaronix) for 12 hours. For the counter electrode, platinum (thickness $\sim 5 \mathrm{~nm}$ ) was sputtered onto a TCO glass substrate. Both electrodes were then sealed using a $25 \mu \mathrm{m}$ thick polymer foil (Surlyn, DuPont) which also acts as a spacer between the electrodes. Electrolyte was injected through two predrilled holes in the counter electrode. The electrolyte was a binary ionic liquid mixture in a volume ratio 13:7 of 1-propyl-3-methyl-imidazolium iodide (Iolitec) mixed with 1-ethyl-3-methyl-imidazolium tetracyanoborate (Merck), $0.5 \mathrm{M}$ methyl benzimidazol, and $0.1 \mathrm{M}$ guanidinium thiocyanate. The concentration of $\mathrm{I}_{2}$ was $0.2 \mathrm{M}$. Three identical DSSCs were assembled for each material combination, each with an active area ranging from 0.58 to $0.72 \mathrm{~cm}^{2}$. Before characterization the cells were stored in the dark for 24 hours to allow the electrolyte to penetrate into the $\mathrm{TiO}_{2}$ pores. 
2.3. Characterization. The $I-V$ characterization was performed using an Oriel Class ABA solar simulator equipped with a $1.5 \mathrm{G}$ air mass filter, the spectrum of which closely matches the required AM1.5 spectrum. In accordance with the IEC 60904-3 standard the short-circuit current mismatch parameter was calculated in conjunction with a calibrated cSi reference solar cell, covered with a KG5 glass filter; the level of standard illumination ( 1 sun, $100 \mathrm{~mW} / \mathrm{m}^{2}$ ) was determined. The cells were also masked to leave only the active area of the cell exposed, which is stated as the most rigorous condition regarding the cell's efficiency. $I-V$ characteristics of the cells were then measured using a Keithley 238 source meter by applying a voltage and measuring the current. The cells were scanned stepwise $(10 \mathrm{mV})$ from $0 \mathrm{~V}$ (short circuit regime) to $0.9 \mathrm{~V}$ (beyond $V_{\mathrm{OC}}$ ).

The UV-vis optical measurements (total transmittance $T_{\text {TOT }}$ and reflectance $R_{\text {TOT }}$ ) were performed on a Lambda 950 Perkin Elmer spectrophotometer equipped with a $150 \mathrm{~mm}$ Ulbricht integration sphere coated with Spectralon. The spectra were recorded from 300 to $800 \mathrm{~nm}$ in decrements of $5 \mathrm{~nm}$. Absorption was calculated accordingly to the $A=100 \%-R_{\mathrm{TOT}}-T_{\mathrm{TOT}}$.

External quantum efficiencies (EQEs) were measured without bias light using an Xe lamp and a monochromator (70525 Arc Lamp Apex Illuminator and Cornerstone 260 Monochromator, Oriel, Newport) at increments of $5 \mathrm{~nm}$ from 300 to $800 \mathrm{~nm}$. The monochromatic light was focused so that the beam was smaller than the active areas of both the reference photodetector and the DSSCs. A stable reading was obtained after a $3 \mathrm{~s}$ delay between setting the wavelength and taking a current measurement.

The amount of the dye adsorbed on the $\mathrm{TiO}_{2}$ layer was determined with UV-vis spectroscopy. The Ruthenium dye was firstly detached from the $\mathrm{TiO}_{2}$ layers using $0.02 \mathrm{M}$ $\mathrm{NaOH}$ (Merck); the dye solution has been diluted with $0.02 \mathrm{M}$ $\mathrm{NaOH}$ to $50 \mathrm{~mL}$ before obtaining $\mathrm{UV}$-vis spectra. In order to determine the amount of dye adsorbed on the $\mathrm{TiO}_{2}$ layers a calibration curve was made. For the calibration curve and the evaluation of the samples concentration the absorbance peak of the dye at the $500 \mathrm{~nm}$ has been considered.

\section{Results and Discussion}

Herein we present the results of the very simplified integration of the Ag NPs within the porous $\mathrm{TiO}_{2}$ layer. The Ag NPs within the $\mathrm{TiO}_{2}$ layers were prepared using three different solutions, that is, $\mathrm{Ag}_{\mathrm{ISO}}, \mathrm{Ag}_{\mathrm{EG}}$, and $\mathrm{Ag} / \mathrm{TiO}_{2}$ (see Section 2). In Section 3.1 the influence of the heat treatment temperature on the formation of $\mathrm{Ag}$ NPs by measuring the absorption spectra is presented. The $\mathrm{TiO}_{2}$ layers with Ag NPs were tested also in the DSSCs and the results were compared with the cells without Ag NPs. We have evaluated the DSSCs by measuring the $I-V$ characteristic, EQEs, and the amounts of the adsorbed dye (Section 3.2). Section 3.3 deals with the stability of the DSSCs containing Ag NPs. The performance of the DSSCs has been remeasured three months after the manufacturing.
Additionally, the degradation of the $\mathrm{TiO}_{2}$ layers containing $\mathrm{Ag}_{\text {ISO }} / \mathrm{TiO}_{2}$ or $\mathrm{Ag}_{\mathrm{ISO}} / \mathrm{PVP}$ core/shell NPs due to the exposure to the $\mathrm{I}_{3}{ }^{-} / \mathrm{I}^{-}$electrolyte is presented.

3.1. Ag NPs Preparation. The influence of the heat treatment temperature on the formation of Ag NPs was evaluated by optical spectroscopy. The absorption spectra $(A=100 \%-$ $R_{\text {TOT }}-T_{\text {TOT }}$ ) of the $\mathrm{TiO}_{2}$ layers (reference) deposited on microscope glass and further impregnated with $\mathrm{Ag}_{\mathrm{ISO}}, \mathrm{Ag}_{\mathrm{EG}}$, and $\mathrm{Ag} / \mathrm{TiO}_{2}$ are presented in Figures 3(a), 3(b), and 3(c).

The $\mathrm{Ag}_{\text {ISO }}$ NPs within the porous $\mathrm{TiO}_{2}$ layer are formed already at $100^{\circ} \mathrm{C}$ visible as a homogeneous dark red layer, shown in Figure 3(a). The absorption enhancement (compared to the reference $\mathrm{TiO}_{2}$ layer without NPs) is noticeable above $365 \mathrm{~nm}$ reaching the enhancement peak $\left(\Delta A=A_{\mathrm{Ag} x}-\right.$ $A_{\text {ref }}$ ) around $410 \mathrm{~nm}$. A further increase in the heat treatment temperature up to $220^{\circ} \mathrm{C}$ gradually increases the absorption without changing the shape of the curve, while a further increase in the temperature to $300^{\circ} \mathrm{C}$ noticeably decreases the absorption and changes the shape of the curve, that is, the layers become grey. In a further study the heat treatment at $220^{\circ} \mathrm{C}$ was used for the preparation of $\mathrm{TiO}_{2}$ layer with $\mathrm{Ag}_{\text {ISO }}$ NPs. The optimal heat treatment temperature where the enhancement is most pronounced is $220^{\circ} \mathrm{C}$.

Similar absorption enhancement and optimal heat treatment temperature at $220^{\circ} \mathrm{C}$ was found for $\mathrm{Ag}_{\mathrm{EG}} \mathrm{NPs}$ (without shell), as shown in Figure 3(b). This is in accordance with our expectation since only the ethylene glycol instead of isopropanol was used in solution 2. In both cases the organic components decompose and reduce the $\mathrm{Ag}^{+}$to $\mathrm{Ag}^{0}$ while leaving the Ag NPs on the surface of the $\mathrm{TiO}_{2}$. However, the $\mathrm{Ag}_{\mathrm{EG}}$ samples are less homogeneous which is probably related to the different surface tension and viscosity of the ethylene glycol.

The absorption of the $\mathrm{Ag} / \mathrm{TiO}_{2}$ core/shell NPs are presented in Figure 3(c). In this case the plasmonic enhancement cannot be compared with the bare $\mathrm{TiO}_{2}$ layer on a microscope glass substrate (black full line in Figure 3(c)) since solution 3 (which includes the $\mathrm{TiO}_{2}$ sol) is expected to form not only $\mathrm{Ag} / \mathrm{TiO}_{2}$ core/shell NPs but also a thin overlayer on the porous $\mathrm{TiO}_{2}$ layer. Therefore, a new reference having a thin "shell" $\mathrm{TiO}_{2}$ overlayer has been used; that is, the porous $\mathrm{TiO}_{2}$ layer has been dip-coated into a $\mathrm{TiO}_{2}$ sol (speed $10 \mathrm{~cm} / \mathrm{min}$ ) and heat treated afterwards at $220^{\circ} \mathrm{C}$ for 1 hour. For $\mathrm{Ag} / \mathrm{TiO}_{2}$ NPs the colour of the samples was greyish (Figure 3(c)) showing significantly smaller absorption enhancement. The absorption enhancement can be only found at $220^{\circ} \mathrm{C}$ while heat treatment at lower or higher temperatures shows even deterioration in absorbance compared to the reference. The minor enhancement might be observed if each studied heat treatment temperature would have its own reference produced at the same temperature. Nevertheless, the $220^{\circ} \mathrm{C}$ seem to be the optimal heat treatment also for the formation of $\mathrm{Ag} / \mathrm{TiO}_{2}$ core/shell NPs.

3.2. DSSCs with AgNPs. The $\mathrm{TiO}_{2}$ layers with $\mathrm{Ag} \mathrm{NPs}$ formed at $220^{\circ} \mathrm{C}$ from different precursors have been tested also in DSSC and the results are compared with the DSSC without Ag 


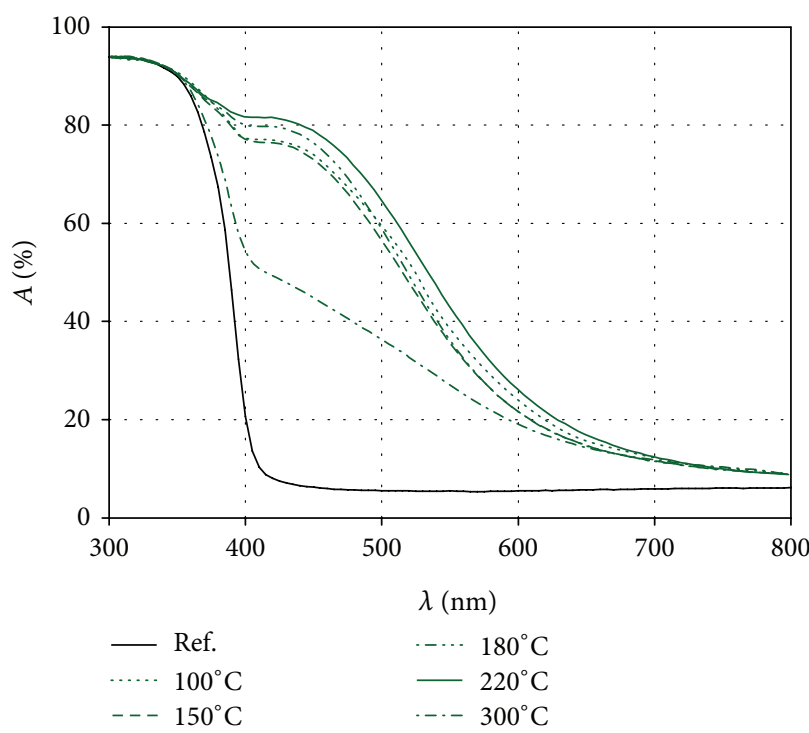

(a)

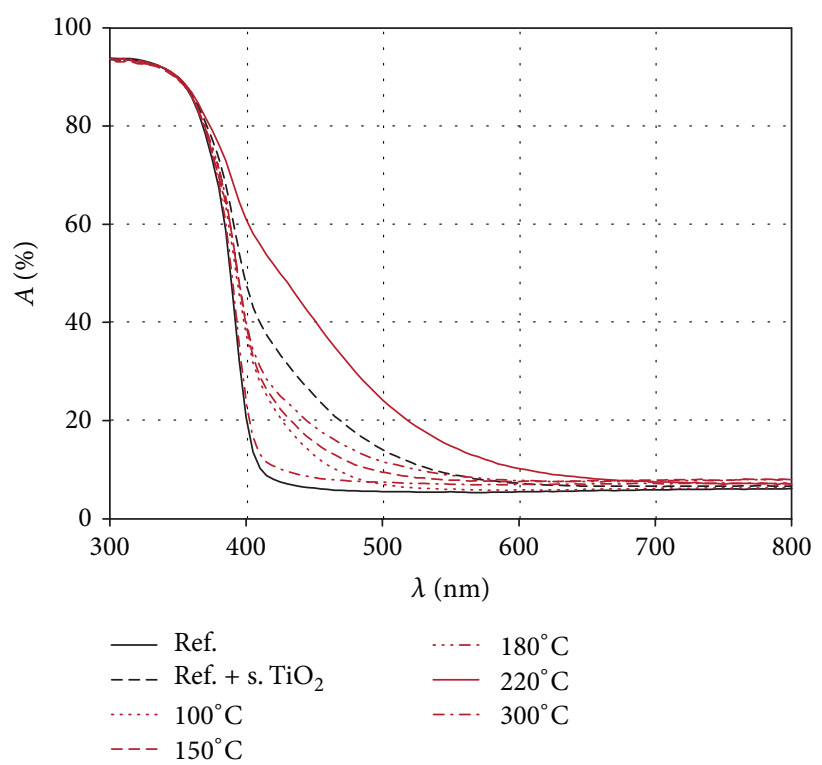

(c)

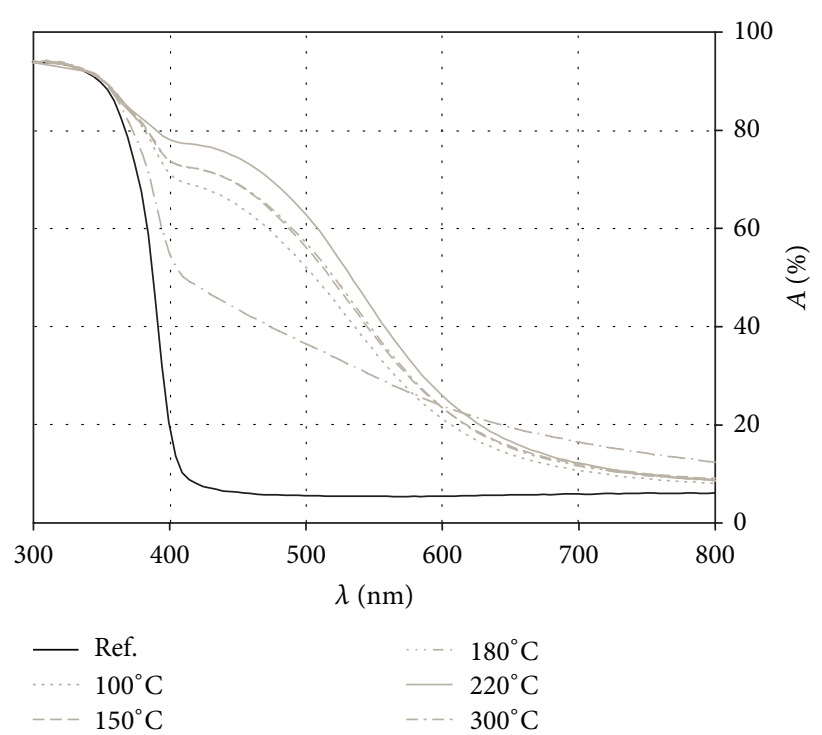

(b)

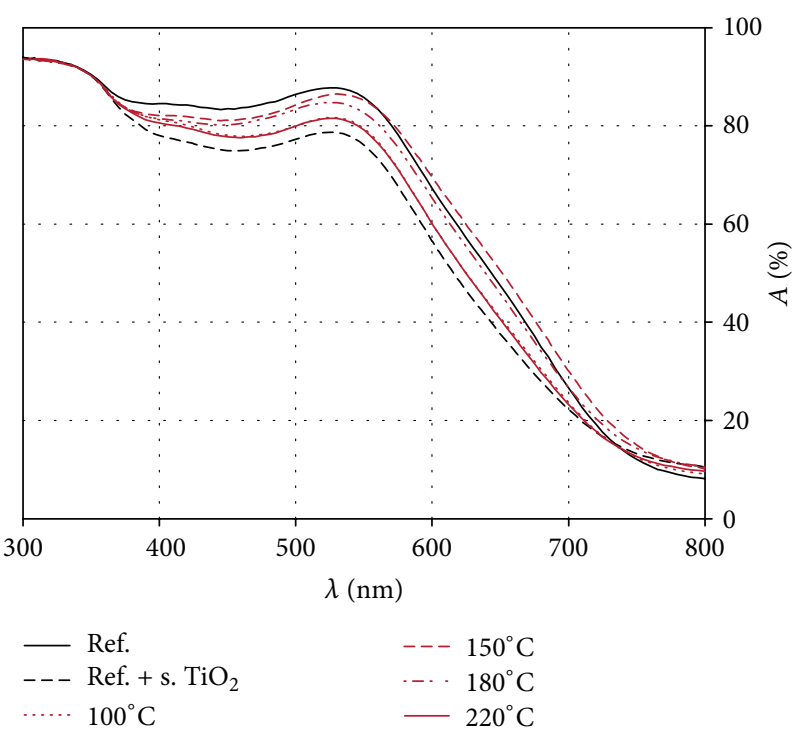

(d)

Figure 3: $(\mathrm{a}-\mathrm{c})$ The absorption $\left(A=100 \%-R_{\mathrm{TOT}}-T_{\mathrm{TOT}}\right)$ of the $\mathrm{Ag}_{\mathrm{ISO}}$ (a) and $\mathrm{Ag}_{\mathrm{EG}}$ (b) NPs (without shell) and $\mathrm{Ag} / \mathrm{TiO} \mathrm{C}_{2}$ core/shell NPs (c) located within the undyed $\mathrm{TiO}_{2}$ layer on microscope glass substrate heat treated at different temperatures. The absorption of bare $\mathrm{TiO}_{2}$ layer (black full line) and the bare $\mathrm{TiO}_{2}$ layer covered with a thin "shell" $\mathrm{TiO}_{2}$ layer (black dashed line) on a microscope glass substrate are shown for the reference. (d) The same as (c) but dyed porous $\mathrm{TiO}_{2}$ layers.

NPs. The $\mathrm{Ag}_{\mathrm{ISO}}$ and $\mathrm{Ag}_{\mathrm{EG}} \mathrm{NPs}$ studied in this section were not protected with a sol-gel $\mathrm{TiO}_{2}$ or PVP shell. The $\mathrm{TiO}_{2}$ layers with Ag NPs were immersed into a dye solution. The amount of the dye molecules attached to the $\mathrm{TiO}_{2}$ surface of different layers was evaluated spectroscopically (see Section 2). The results of dye loading are gathered in Figure 4 and regardless of the solution used for Ag NPs preparation the $\mathrm{TiO}_{2}$ layers with Ag NPs show smaller dye loading. The results confirm that the inclusion of the Ag NPs within the porous $\mathrm{TiO}_{2}$ layers reduces the inner surface area available for the dye attachment.

The current-voltage characteristics $(I-V)$ of all DSSCs have been measured. Typical $I-V$ for the reference and for the DSSCs with Ag NPs $\left(\mathrm{Ag}_{\mathrm{ISO}}, \mathrm{Ag}_{\mathrm{EG}}\right.$, and $\left.\mathrm{Ag} / \mathrm{TiO}_{2}\right)$ measured after manufacturing (a) and after keeping the cells in the dark at room temperature for three months (b) are presented in Figure 5. In addition the averaged performance parameters (short circuit current $J_{\mathrm{sc}}$, open circuit voltage $V_{\mathrm{OC}}$, fill factor 


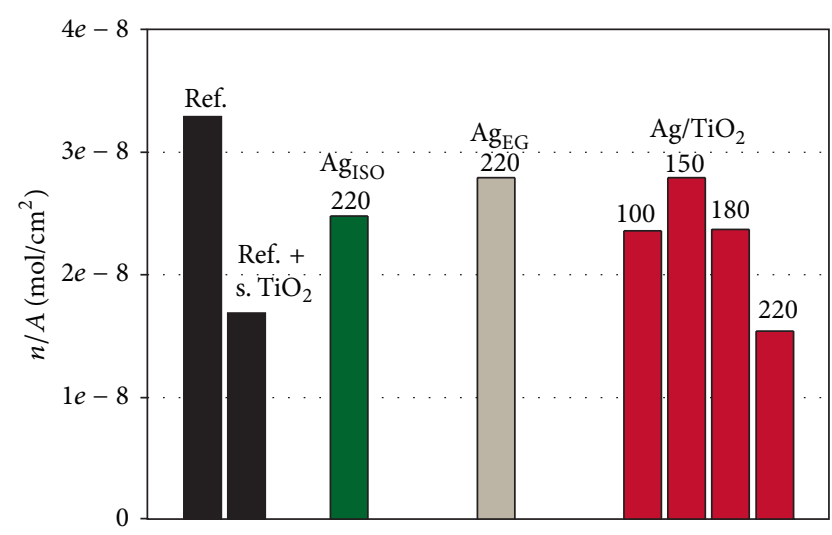

FIgUre 4: The amount of the dye molecules attached to the surface of the active layers containing $\mathrm{Ag}_{\mathrm{ISO}}, \mathrm{Ag}_{\mathrm{EG}}$, or $\mathrm{Ag} / \mathrm{TiO}_{2} \mathrm{NPs}$. The $\mathrm{Ag}$ NPs were thermally treated at different temperatures as denoted at the top of the columns (values in ${ }^{\circ} \mathrm{C}$ ). The results for porous $\mathrm{TiO}_{2}$ layer without NPs (ref) and porous $\mathrm{TiO}_{2}$ layer covered with a "shell" $\mathrm{TiO}_{2}$ layer (ref. $+\mathrm{s}$. $\mathrm{TiO}_{2}$ ) are shown for reference.

TABLE 1: Performance parameters $\left(J_{\mathrm{SC}}, V_{\mathrm{OC}}, \mathrm{FF}\right.$, and $\left.\eta\right)$ of reference DSSCs and DSSCs with Ag NPs $\left(\mathrm{Ag}_{\mathrm{ISO}}, \mathrm{Ag}_{\mathrm{EG}}\right.$, and $\left.\mathrm{Ag} / \mathrm{TiO}_{2}\right)$ measured after manufacturing/after 3 months.

\begin{tabular}{lcccc}
\hline Cell & $J_{\mathrm{SC}}\left(\mathrm{mA} / \mathrm{cm}^{2}\right)$ & $V_{\mathrm{OC}}(\mathrm{mV})$ & $\mathrm{FF}(\%)$ & $\eta(\%)$ \\
\hline Ref. & $9.0 / 9.2$ & $673 / 708$ & $49 / 55$ & $3.0 / 3.6$ \\
$\mathrm{Ag}_{\mathrm{ISO}}$ & $9.4 / 9.1$ & $687 / 725$ & $52 / 58$ & $3.4 / 3.9$ \\
$\mathrm{Ag}_{\mathrm{EG}}$ & $5.9 / 7.0$ & $576 / 620$ & $53 / 56$ & $1.8 / 2.4$ \\
$\mathrm{Ag} / \mathrm{TiO}_{2}$ & $8.4 / 9.2$ & $635 / 684$ & $51 / 57$ & $2.7 / 3.6$ \\
\hline
\end{tabular}

FF, and conversion efficiency $\eta$ ) of three identical cells are gathered in Table 1.

The DSSC with $\mathrm{Ag}_{\text {ISO }}$ NPs is the only structure where a small increase in $J_{\mathrm{SC}}$ was observed compared to the reference structure. The increase can be related to the plasmonic effect since the DSSCs with $\mathrm{Ag}_{\text {ISO }}$ NPs have a smaller amount of dye molecules attached to the $\mathrm{TiO}_{2}$ than the reference DSSCs (see Figure 4).

The DSSCs with $\mathrm{Ag} / \mathrm{TiO}_{2}$ have smaller $J_{\mathrm{SC}}$ than the reference (which has no additional "shell" $\mathrm{TiO}_{2}$ overlayer), as shown in Table 1 . This is according to our expectation since a thin "shell" $\mathrm{TiO}_{2}$ overlayer is formed together with the formation of $\mathrm{Ag} / \mathrm{TiO}_{2} \mathrm{NPs}$. It should be mentioned that the formation of $\mathrm{a} \mathrm{TiO}_{2}$ overlayer on the top of the porous $\mathrm{TiO}_{2}$ layer significantly decreases the dye loading reaching a half value compared to the reference porous layer (Figure 4). Therefore, the performance of the DSSCs with $\mathrm{Ag} / \mathrm{TiO}_{2}$ cannot be directly compared with the reference DSSCs which has no $\mathrm{TiO}_{2}$ overlayer (ref., Table 1). However, we can see that the $J_{\mathrm{SC}}$ of $\mathrm{Ag} / \mathrm{TiO}_{2}$ is only $7 \%$ lower than the reference $\left(9.0 \mathrm{~mA} / \mathrm{cm}^{2}\right.$ for the ref. versus $8.4 \mathrm{~mA} / \mathrm{cm}^{2}$ for the $\mathrm{Ag} / \mathrm{TiO}_{2}$, Table 1) although the amount of the adsorbed dye is halved (Figure 4). This is another indirect proof of the plasmonic effect in the DSSC. The results are well in accordance also with the optical measurements presented in Figure 3(d) showing a higher absorption of a dyed porous $\mathrm{TiO}_{2}$ layer containing $\mathrm{Ag} /$
$\mathrm{TiO}_{2}$ core/shell NPs (Figure 3(d), red full line) than a dyed $\mathrm{TiO}_{2}$ layer covered with a thin "shell" $\mathrm{TiO}_{2}$ (black dashed line) although the amount of the attached dye molecules is in both cases similar $\left(1.7 \times 10^{-8} \mathrm{~mol} / \mathrm{cm}^{2}\right.$ for the reference with a "shell" $\mathrm{TiO}_{2}$ overlayer and $1.6 \times 10^{-8} \mathrm{~mol} / \mathrm{cm}^{2}$ for the $\mathrm{Ag} / \mathrm{TiO}_{2}$, Figure 4).

The DSSCs with $\mathrm{Ag}_{\mathrm{EG}}$ have significantly smaller $J_{\mathrm{SC}}$ than the reference although a comparable $J_{S C}$ to DSSC with $\mathrm{Ag}_{\text {ISO }} \mathrm{NPs}$ would be expected due to similar absorption enhancement (Figures 3(a) and 3(b)) and a similar amount of the attached dye (Figure 4). The origin for the decrease is unknown. It might be related to the very inhomogeneous deposition of the Ag NPs due to different surface tension of the ethylene glycol compared to the isopropanol and/or poor attachment of the Ag NPs to the porous $\mathrm{TiO}_{2}$ layer. This creates a very low concentration of the $\mathrm{Ag}_{\mathrm{EG}} \mathrm{NPs}$ at the edges of the DSSCs and a very high concentration in the centre which increases the parasitic absorption within the NPs and significantly decreases the $J_{\mathrm{SC}}$.

The normalized EQEs of the DSSCs are presented in Figure 6 (the EQEs were normalized to 0.8 at $345 \mathrm{~nm}$ ). According to the expectation, the EQEs show the same trends as observed for the $J_{\mathrm{SC}}$ determined from $I-V$ measurements; that is, the only enhancement is found for DSSCs with $\mathrm{Ag}_{\text {ISO }}$ while smaller values were observed for DSSCs with $\mathrm{Ag}_{\mathrm{EG}}$ and $\mathrm{Ag} / \mathrm{TiO}_{2}$. The increase or decrease in EQEs is observed above $365 \mathrm{~nm}$ which is in agreement with the absorption measurements (Figure 3).

The $V_{\mathrm{OC}}$ of the DSSCs are gathered in Table 1 . The DSSCs with $\mathrm{Ag}_{\text {ISO }}$ NPs have on average $14 \mathrm{mV}$ higher $V_{\mathrm{OC}}$ than the reference DSSC which might be related to the upward shift of the Fermi level induced by the Ag NPs $[43,53]$. The DSSCs with $\mathrm{Ag} / \mathrm{TiO}_{2} \mathrm{NPs}$ have $38 \mathrm{mV}$ smaller $V_{\mathrm{OC}}$ than the reference. This could be explained by a smaller dye loading which reduces the number of injected electrons in a conduction band of the $\mathrm{TiO}_{2}$. Additionally, the smaller dye loading might leave a larger part of the $\mathrm{TiO}_{2}$ surface exposed to the electrolyte which increases the recombinations. Both effects shift the Fermi level downward and decrease the $V_{\mathrm{OC}}$. A significantly smaller $V_{\mathrm{OC}}$ for the DSSCs with $\mathrm{Ag}_{\mathrm{EG}}$ is difficult to explain but might be due to the poor attachment of Ag NPs that act as strong recombination centres.

The FF is practically unaffected by the NPs; therefore the $\eta$ is the outcome of the $J_{\mathrm{SC}}$ and $V_{\mathrm{OC}}$. The increase in $\eta$ was found only for the DSSCs with $\mathrm{Ag}_{\text {ISO }}$ while the DSSCs with $\mathrm{Ag}_{\mathrm{EG}}$ and $\mathrm{Ag} / \mathrm{TiO}_{2}$ NPs show a lower $\eta$ than the reference DSSCs.

3.3. Stability of Ag NPs. The DSSCs have been remeasured 3 months after manufacturing, that is, after keeping the cells in the dark under open circuit conditions for 3 months (Table 1). The DSSC with $\mathrm{Ag}_{\text {ISO }} \mathrm{NPs}$ is the only structure where a decrease in $J_{\mathrm{SC}}$ was observed $(-3 \%)$ while the other DSSCs showed an increase. The $J_{S C}$ of the reference DSSC increased for $2 \%$ while the DSSCs with $\mathrm{Ag}_{\mathrm{EG}}$ and $\mathrm{Ag} / \mathrm{TiO}_{2}$ increased for $18 \%$ and $9 \%$, respectively. Interestingly, for the $J_{\mathrm{SC}}$ of reference, $\mathrm{Ag}_{\text {ISO }}$ and $\mathrm{Ag} / \mathrm{TiO}_{2}$ DSSCs became practically alike (Figure 5(b)) which might be related to the degradation of 


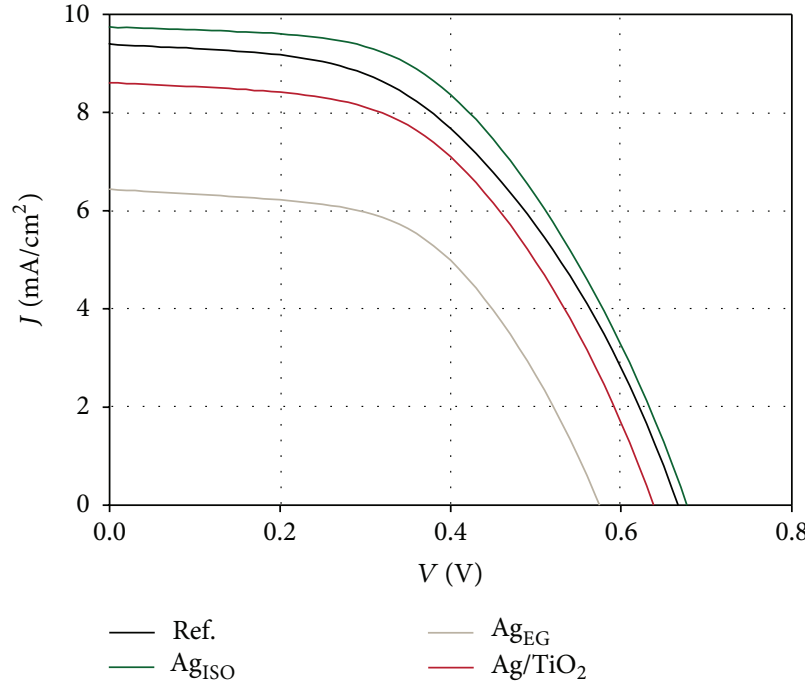

(a)

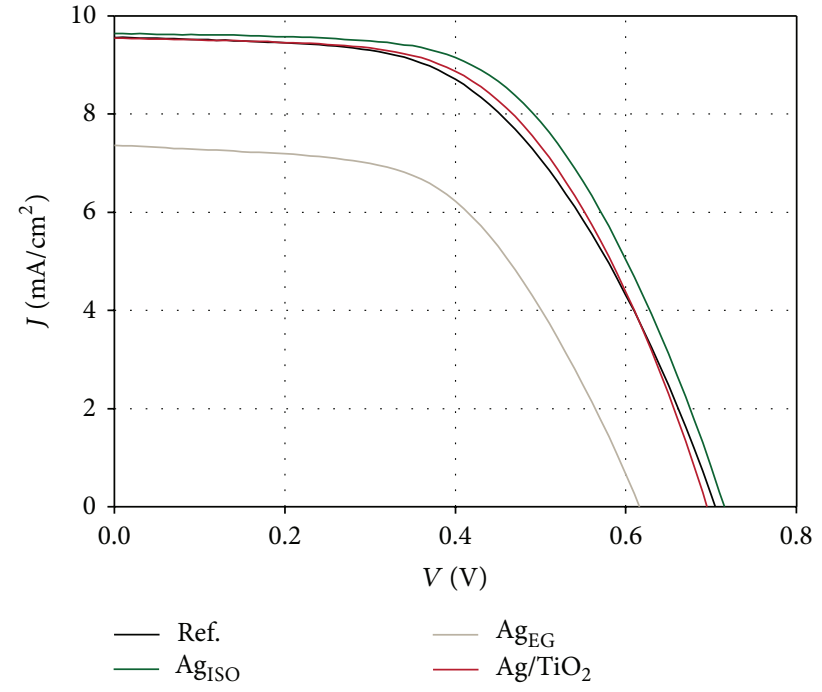

(b)

Figure 5: The current-voltage ( $I-V)$ characteristics of typical reference DSSC and typical DSSCs with $\mathrm{Ag} \mathrm{NPs}_{(\mathrm{Ag}}, \mathrm{Ag}_{\mathrm{EG}}$, and $\left.\mathrm{Ag} / \mathrm{TiO}_{2}\right)$ that were measured after manufacturing (a) and after 3 months (b).

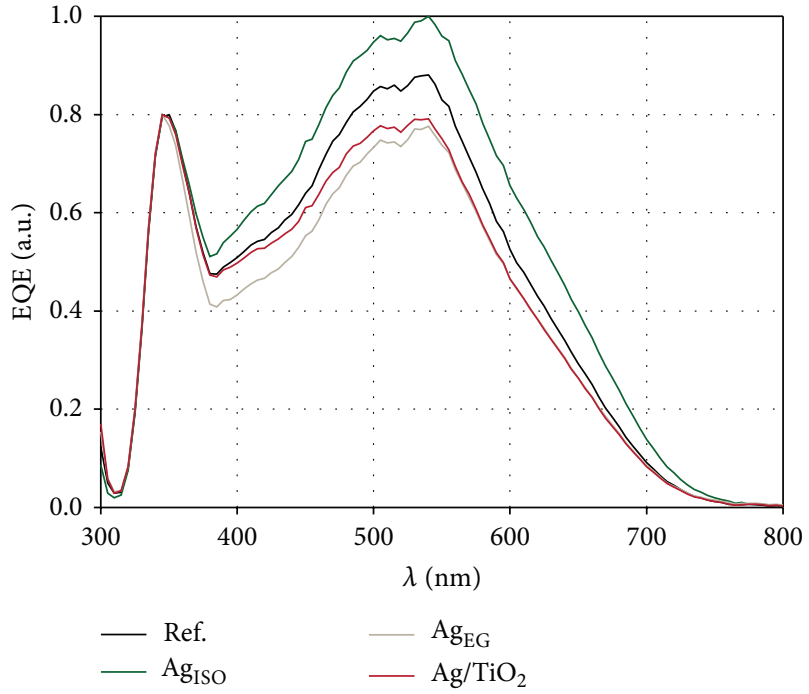

FIGURE 6: The normalized EQEs of the DSSCs containing Ag or $\mathrm{Ag}_{\mathrm{EG}} \mathrm{NPs}$ or $\mathrm{Ag} / \mathrm{TiO}_{2}$ core/shell NPs. The DSSCs without NPs or "shell" $\mathrm{TiO}_{2}$ overlayer is given for reference. The EQEs were normalized to 0.8 at $345 \mathrm{~nm}$.

the Ag NPs. Additionally all cells showed a 5-8\% and 11$12 \%$ increase in the $V_{\mathrm{OC}}$ and FF, respectively. These changes cannot be associated with the presence of Ag NPs since similar variations were observed also for reference DSSCs. The $\eta$ increased for $20,15,33$, and $33 \%$, relatively, for the reference and the DSSCs with $\mathrm{Ag}_{\mathrm{ISO}}, \mathrm{Ag}_{\mathrm{EG}}$, and $\mathrm{Ag} / \mathrm{TiO}_{2}$ NPs. The $\mathrm{Ag}_{\text {ISO }}$ DSSC has still the highest performance but the differences became less distinctive. The degradation of the Ag NPs in the presence of $\mathrm{I}_{3}^{-} / \mathrm{I}^{-}$based electrolyte is not surprising and is in accordance with the literature. A quick degradation of the Ag NPs was found by Lin et al. [46] and

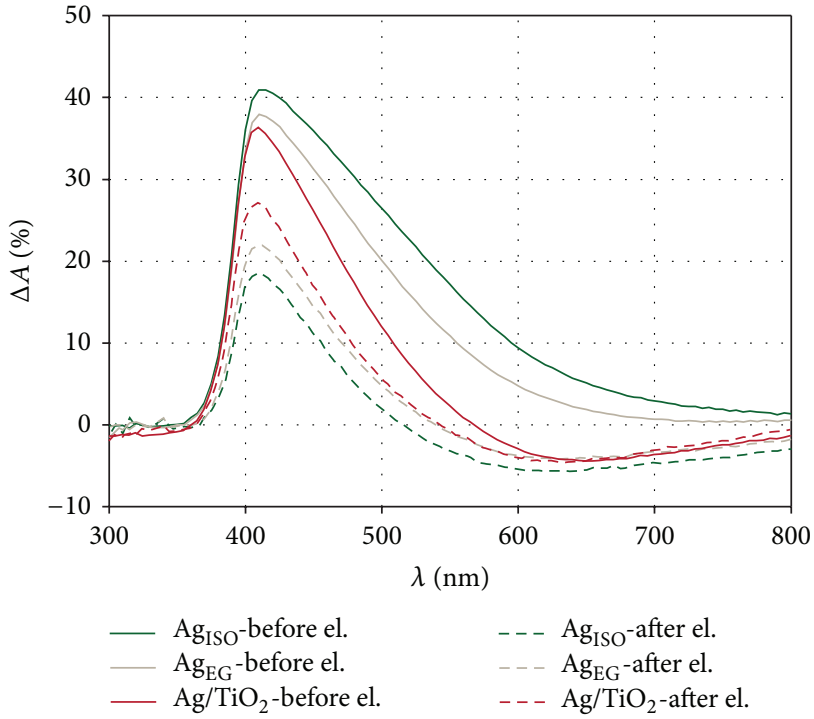

FIgURE 7: The absorption enhancement $\left(\Delta A=A_{\mathrm{Agx}}-A_{\text {ref }}\right)$ of the undyed $\mathrm{TiO}_{2}$ layers with $\mathrm{Ag}_{\mathrm{ISO}}, \mathrm{Ag}_{\mathrm{EG}}$, and $\mathrm{Ag} / \mathrm{TiO}_{2} \mathrm{NPs}$ before (full lines) and after being exposed to the $\mathrm{I}_{3}{ }^{-} / \mathrm{I}^{-}$electrolyte (dashed lines). All NPs were thermally treated at $220^{\circ} \mathrm{C}$.

Thanachayanont et al. [58] who also found a decrease in $J_{\mathrm{SC}}$ and an increase in $V_{\mathrm{OC}}$ and FF during the 10 days stability study.

The changes (especially in $J_{\mathrm{SC}}$ ) in remeasured DSSCs suggest that the dye molecules produce a certain degree of protection but they cannot prevent the degradation entirely. Therefore, the stability of the Ag NPs upon exposure to the aggressive $\mathrm{I}_{3}{ }^{-} / \mathrm{I}^{-}$based electrolyte was studied.

The absorption enhancements $\left(\Delta A=A_{\text {Agx }}-A_{\text {ref }}\right)$ of the $\mathrm{Ag}_{\mathrm{ISO}}, \mathrm{Ag}_{\mathrm{EG}} \mathrm{NPs}$, and $\mathrm{Ag} / \mathrm{TiO}_{2}$ core/shell NPs within 

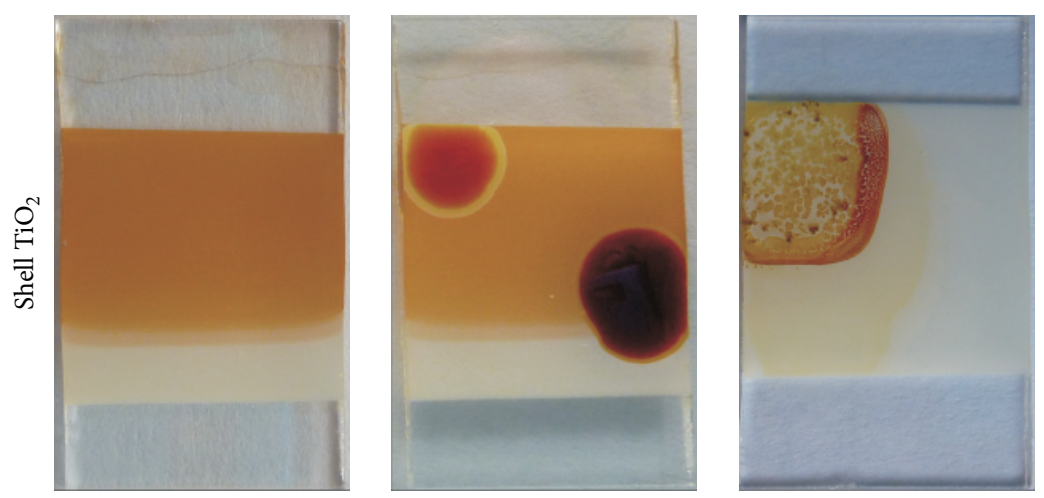

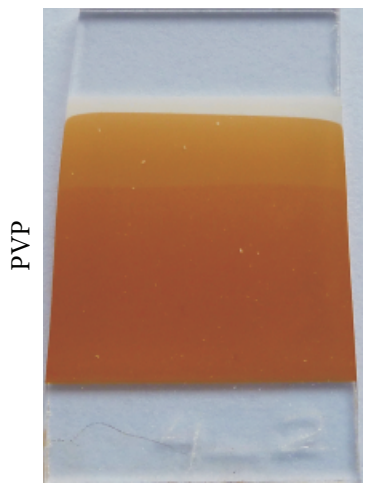

(a)

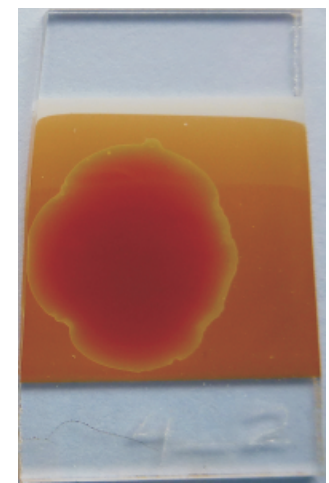

(b)

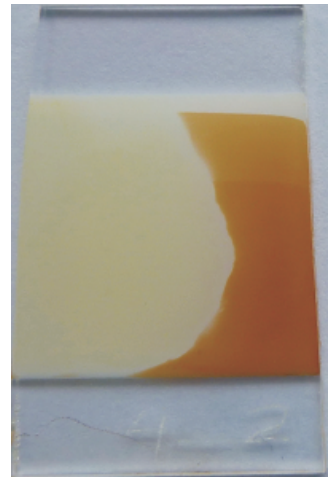

(c)

Figure 8: Degradation of the $\mathrm{Ag}_{\text {ISO }}$ NPs coated with either a "shell" $\mathrm{TiO}_{2}$ or a PVP shell (a) layer before and (b) immediately after being exposed to the electrolyte, and (c) after 24 hours. The $\mathrm{Ag}_{\text {ISO }}$ NPs located within undyed porous $\mathrm{TiO}_{2}$ layer were thermally treated at $220^{\circ} \mathrm{C}$.

undyed porous $\mathrm{TiO}_{2}$ layers are presented in Figure 7. The full lines present the $\Delta A$ after production while the dashed lines present the $\Delta A$ after exposure of the layer to the electrolyte for 24 hours under ambient conditions. As expected the $\Delta A$ decrease substantially for the unprotected $\mathrm{Ag}_{\mathrm{EG}}$ and especially $\mathrm{Ag}_{\text {ISO }}$ NPs. Surprisingly, a small decrease in $\Delta A$ of the $\mathrm{Ag} / \mathrm{TiO}_{2}$ core/shell NPs was also observed which reveals that the thin $\mathrm{TiO}_{2}$ shell does not provide sufficient protection required for long term stability.

Since the $\mathrm{Ag} / \mathrm{TiO}_{2}$ core/shell NPs that were formed in a single step do not provide sufficient protection we used a secondary step to protect the $\mathrm{Ag}_{\text {ISO }}$ NPs with either a thin sol-gel $\mathrm{TiO}_{2}$ or PVP shell, which should protect the NPs from the electrolyte and allow the dye attachment [52]. The protected NPs were then exposed to the $\mathrm{I}_{3}{ }^{-} / \mathrm{I}^{-}$electrolyte and the photographs were taken at different time periods, Figure 8. A substantial degradation of the protected Ag NPs was noticed if the sol-gel $\mathrm{TiO}_{2}$ layer was used. The thin $\mathrm{TiO}_{2}$ layer prepared via sol-gel route has a certain degree of porosity which allows the penetration of the electrolyte. Moreover, in our study the PVP shell did not protect the $\mathrm{Ag}_{\text {ISO }}$ NPs although it provided adequate protection for the $\mathrm{Au}$ NPs [52]. In addition a few different techniques to prepare $\mathrm{TiO}_{2}$ shells around NPs can be found in the literature. Dang et al. [42] synthesized core shell NPs before being deposited on the porous $\mathrm{TiO}_{2}$ layer. On the other hand, a compact $\mathrm{TiO}_{2}$ shell around Ag NPs could be formed afterwards by atomic layer deposition $[39,40]$ or by calcination of the $\mathrm{Ag}-\mathrm{TiO}_{2}$ films refluxed with a Titanium (IV) isoproxide in isopropyl alcohol solution [45].

\section{Conclusions}

A plasmonic effect of Ag NP in the dye-sensitized solar cells (DSSCs) has been confirmed. We used three different solutions containing silver nitrate in isopropanol, ethylene glycol, or isopropanol/ $\mathrm{TiO}_{2}$ sol for dip-coating of porous $\mathrm{TiO}_{2}$ layers. The results confirmed the formation of the Ag NPs without/with shells within a porous $\mathrm{TiO}_{2}$ layer. The optimal heat treatment temperature of the dip-coated layers, which gave the most intensive plasmonic enhancements, was $220^{\circ} \mathrm{C}$ for all three solutions. However, the ethylene glycol solution of silver nitrate gave a very nonhomogeneous distribution of Ag NPs over the $\mathrm{TiO}_{2}$ layers. On the other hand, the results show that the formation of the Ag NPs from the isopropanol solution leads to a uniform formation of the NPs throughout the layer giving also the highest plasmonic enhancement in DSSCs. The incorporation of the Ag NPs in the porous 
$\mathrm{TiO}_{2}$ layer decreases the dye loading but increases the short circuit current which is a direct indication of the plasmonic effect. The plasmonic effect has been confirmed also by EQE measurements. Nevertheless, the degradation of $\mathrm{Ag}$ NPs was observed in the cells that have been measured again three months after the manufacturing. In addition, the study confirmed that neither a thin sol-gel $\mathrm{TiO}_{2}$ overlayer nor a poly(4-vinylpyridine) can provide sufficient protection for the long term stability of the Ag NPs against the corrosion of the $\mathrm{I}_{3}{ }^{-} / \mathrm{I}^{-}$electrolyte.

\section{Conflict of Interests}

The authors declare that there is no conflict of interests regarding the publication of this paper.

\section{Acknowledgments}

Mateja Hočevar is acknowledged for $\mathrm{TiO}_{2}$ paste and electrolyte preparation and Jože Stepan for his help in fabricating the cells. Marko Berginc would like to acknowledge the Slovenian Research Agency (Contract no. Z2-4189-1538) for the funding. The work was also partially funded by the Slovenian Research Agency under the P2/0197 Program. The authors would especially like to acknowledge the bilateral Project between the Laboratory of Photovoltaics and Optoelectronics and CEA (Contract no. Bt-CEA/Q2-0002).

\section{References}

[1] B. O’Regan and M. Grätzel, "A low-cost, high-efficiency solar cell based on dye-sensitized colloidal $\mathrm{TiO}_{2}$ films," Nature, vol. 353, no. 6346, pp. 737-740, 1991.

[2] A. Hagfeldt, G. Boschloo, L. Sun, L. Kloo, and H. Pettersson, "Dye-sensitized solar cells," Chemical Reviews, vol. 110, no. 11, pp. 6595-6663, 2010.

[3] M. I. Asghar, K. Miettunen, J. Halme et al., "Review of stability for advanced dye solar cells," Energy and Environmental Science, vol. 3, no. 4, pp. 418-426, 2010.

[4] M. Berginc, U. Opara Krašovec, and M. Topič, "Outdoor ageing of the dye-sensitized solar cell under different operation regimes," Solar Energy Materials and Solar Cells B, vol. 120, pp. 491-499, 2014.

[5] D. Shi, N. Pootrakulchote, R. Li et al., "New efficiency records for stable dye-sensitized solar cells with low-volatility and ionic liquid electrolytes," Journal of Physical Chemistry C, vol. 112, no. 44, pp. 17046-17050, 2008.

[6] P. Wang, S. M. Zakeeruddin, J. E. Moser, M. K. Nazeeruddin, T. Sekiguchi, and M. Grätzel, "A stable quasi-solid-state dyesensitized solar cell with an amphiphilic ruthenium sensitizer and polymer gel electrolyte," Nature Materials, vol. 2, no. 6, pp. 402-407, 2003.

[7] D. Kuang, C. Klein, S. Ito et al., "High-Efficiency and stable mesoscopic dye-sensitized solar cells based on a high molar extinction coefficient ruthenium sensitizer and nonvolatile electrolyte," Advanced Materials, vol. 19, no. 8, pp. 1133-1137, 2007.

[8] A. Yella, H.-W. Lee, H. N. Tsao et al., "Porphyrin-sensitized solar cells with cobalt (II/III)-based redox electrolyte exceed 12 percent efficiency," Science, vol. 334, no. 6056, pp. 629-634, 2011.
[9] S. Zhang, A. Islam, X. Yang et al., "Improvement of spectral response by co-sensitizers for high efficiency dye-sensitized solar cells," Journal of Materials Chemistry A, vol. 1, no. 15, pp. 4812-4819, 2013.

[10] L. Y. Lin, M. H. Yeh, C. P. Lee et al., "Insights into the co-sensitizer adsorption kinetics for complementary organic dyesensitized solar cells," Journal of Power Sources, vol. 247, pp. 906914, 2014.

[11] C. Qin, Y. Numata, S. Zhang et al., "A near-infrared cis-configured squaraine co-sensitizer for high-efficiency dyesensitized solar cells," Advanced Functional Materials, vol. 23, no. 30, pp. 3782-3789, 2013.

[12] S. Zhanga, X. Yang, C. Qin, Y. Numata, and L. Han, "Interfacial engineering for dye sensitized solar cells," Journal of Materials Chemistry A, 2014.

[13] S. Ito, S. M. Zakeeruddin, R. Humphry-Baker et al., "Highefficiency organic-dye-sensitized solar cells controlled by nanocrystalline- $\mathrm{TiO}_{2}$ electrode thickness," Advanced Materials, vol. 18, no. 9, pp. 1202-1205, 2006.

[14] Z.-S. Wang, H. Kawauchi, T. Kashima, and H. Arakawa, "Significant influence of $\mathrm{TiO}_{2}$ photoelectrode morphology on the energy conversion efficiency of N719 dye-sensitized solar cell," Coordination Chemistry Reviews, vol. 248, no. 13-14, pp. 1381-1389, 2004

[15] A. Hagfeldt and M. Grätzel, "Light-induced redox reactions in nanocrystalline systems," Chemical Reviews, vol. 95, no. 1, pp. 49-68, 1995.

[16] Y. Tachibana, K. Hara, K. Sayama, and H. Arakawa, "Quantitative analysis of light-harvesting efficiency and electron-transfer yield in ruthenium-dye-sensitized nanocrystalline $\mathrm{TiO}_{2}$ solar cells," Chemistry of Materials, vol. 14, no. 6, pp. 2527-2535, 2002.

[17] M. K. Nazeeruddin, P. Péchy, T. Renouard et al., "Engineering of efficient panchromatic sensitizers for nanocrystalline $\mathrm{TiO}_{2}-$ based solar cells," Journal of the American Chemical Society, vol. 123, no. 8, pp. 1613-1624, 2001.

[18] C. J. Barbé, F. Arendse, P. Comte et al., "Nanocrystalline titanium oxide electrodes for photovoltaic applications," Journal of the American Ceramic Society, vol. 80, no. 12, pp. 3157-3171, 1997.

[19] S. Hore, C. Vetter, R. Kern, H. Smit, and A. Hinsch, "Influence of scattering layers on efficiency of dye-sensitized solar cells," Solar Energy Materials and Solar Cells, vol. 90, no. 9, pp. 11761188, 2006.

[20] H.-J. Koo, J. Park, B. Yoo, K. Yoo, K. Kim, and N.-G. Park, "Sizedependent scattering efficiency in dye-sensitized solar cell," Inorganica Chimica Acta, vol. 361, no. 3, pp. 677-683, 2008.

[21] X. Fang, T. Ma, G. Guan, M. Akiyama, T. Kida, and E. Abe, "Effect of the thickness of the Pt film coated on a counter electrode on the performance of a dye-sensitized solar cell," Journal of Electroanalytical Chemistry, vol. 570, no. 2, pp. 257-263, 2004.

[22] X. Fang, T. Ma, G. Guan, M. Akiyama, and E. Abe, "Performances characteristics of dye-sensitized solar cells based on counter electrodes with Pt films of different thickness," Journal of Photochemistry and Photobiology A, vol. 164, no. 1-3, pp. 179$182,2004$.

[23] P. Li, J. Wu, J. Lin, M. Huang, Z. Lan, and Q. Li, "Improvement of performance of dye-sensitized solar cells based on electrodeposited-platinum counter electrode," Electrochimica Acta, vol. 53, no. 12, pp. 4161-4166, 2008.

[24] K. Li, Z. Yu, Y. Luo, D. Li, and Q. Meng, "Recent progress of counter electrodes in nanocrystalline dye-sensitized solar cells," 
Journal of Materials Science and Technology, vol. 23, no. 5, pp. 577-582, 2007.

[25] N. Papageorgiou, W. F. Maier, and M. Grätzel, "An iodine/ triiodide reduction electrocatalyst for aqueous and organic media," Journal of the Electrochemical Society, vol. 144, no. 3, pp. 876-884, 1997.

[26] N. Papageorgiou, P. Liska, A. Kay, and M. Gratzel, "Mediator transport in multilayer nanocrystalline photoelectrochemical cell configurations," Journal of the Electrochemical Society, vol. 146, no. 3, pp. 898-907, 1999.

[27] M. K. Nazeeruddin, R. Humphry-Baker, P. Liska, and M. Grätzel, "Investigation of sensitizer adsorption and the influence of protons on current and voltage of a dye-sensitized nanocrystalline $\mathrm{TiO}_{2}$ solar cell," Journal of Physical Chemistry $B$, vol. 107, no. 34, pp. 8981-8987, 2003.

[28] A. Hagfeldt and M. Grätzel, "Light-induced redox reactions in nanocrystalline systems," Chemical Reviews, vol. 95, no. 1, pp. 49-68, 1995.

[29] M. Grätzel, "Mesoporous oxide junctions and nanostructured solar cells," Current Opinion in Colloid and Interface Science, vol. 4, no. 4, pp. 314-321, 1999.

[30] M. Grätzel, "Photoelectrochemical cells," Nature, vol. 414, no. 6861, pp. 338-344, 2001.

[31] G. Rothenberger, P. Comte, and M. Grätzel, "Contribution to the optical design of dye-sensitized nanocrystalline solar cells," Solar Energy Materials and Solar Cells, vol. 58, no. 3, pp. 321-336, 1999.

[32] M. Berginc, U. Opara Krašovec, M. Hočevar, and M. Topič, "Effect of masking and back reflector on performance of dyesensitized solar cells at different cell temperatures," in Proceedings of the 22nd European Photovoltaic Solar Energy Conference, Milan, Italy, September 2007.

[33] T. L. Temple, G. D. K. Mahanama, H. S. Reehal, and D. M. Bagnall, "Influence of localized surface plasmon excitation in silver nanoparticles on the performance of silicon solar cells," Solar Energy Materials and Solar Cells, vol. 93, no. 11, pp. 1978-1985, 2009.

[34] S. Pillai and M. A. Green, "Plasmonics for photovoltaic applications," Solar Energy Materials and Solar Cells, vol. 94, no. 9, pp. 1481-1486, 2010.

[35] K. R. Catchpole and A. Polman, "Plasmonic solar cells," Optics Express, vol. 16, no. 26, pp. 21793-21800, 2008.

[36] H. A. Atwater and A. Polman, "Plasmonics for improved photovoltaic devices," Nature Materials, vol. 9, no. 3, pp. 205-213, 2010.

[37] C. Noguez, "Surface plasmons on metal nanoparticles: the influence of shape and physical environment," Journal of Physical Chemistry C, vol. 111, no. 10, pp. 3606-3619, 2007.

[38] K. Ishikawa, C.-J. Wen, K. Yamada, and T. Okubo, “The photocurrent of dye-sensitized solar cells enhanced by the surface plasmon resonance," Journal of Chemical Engineering of Japan, vol. 37, no. 5, pp. 645-649, 2004.

[39] S. D. Standridge, G. C. Schatz, and J. T. Hupp, “Toward plasmonic solar cells: protection of silver nanoparticles via atomic layer deposition of $\mathrm{TiO}_{2}$," Langmuir, vol. 25, no. 5, pp. 25962600, 2009.

[40] S. D. Standridge, G. C. Schatz, and J. T. Hupp, "Distance dependence of plasmon-enhanced photocurrent in dye-sensitized solar cells," Journal of the American Chemical Society, vol. 131, no. 24, pp. 8407-8409, 2009.
[41] C. Wen, K. Ishikawa, M. Kishima, and K. Yamada, "Effects of silver particles on the photovoltaic properties of dye-sensitized $\mathrm{TiO}_{2}$ thin films," Solar Energy Materials and Solar Cells, vol. 61, no. 4, pp. 339-351, 2000.

[42] X. Dang, J. Qi, M. T. Klug et al., “Tunable localized surface plasmon-enabled broadband light-harvesting enhancement for high-efficiency panchromatic dye-sensitized solar cells," Nano Letters, vol. 13, no. 2, pp. 637-642, 2013.

[43] K. Guo, M. Li, X. Fang et al., "Preparation and enhanced properties of dye-sensitized solar cells by surface plasmon resonance of Ag nanoparticles in nanocomposite photoanode," Journal of Power Sources, vol. 230, pp. 155-160, 2013.

[44] S.-J. Lin, K.-C. Lee, J.-L. Wu, and J.-Y. Wu, "Plasmon-enhanced photocurrent in dye-sensitized solar cells," Solar Energy, vol. 86, no. 9, pp. 2600-2605, 2012.

[45] N. C. Jeong, C. Prasittichai, and J. T. Hupp, "Photocurrent enhancement by surface plasmon resonance of silver nanoparticles in highly porous dye-sensitized solar cells," Langmuir, vol. 27, no. 23, pp. 14609-14614, 2011.

[46] S.-J. Lin, K.-C. Lee, J.-L. Wu, and J.-Y. Wu, "Enhanced performance of dye-sensitized solar cells via plasmonic sandwiched structure," Applied Physics Letters, vol. 99, no. 4, Article ID 043306, 2011.

[47] W. Hou, P. Pavaskar, Z. Liu, J. Theiss, M. Aykol, and S. B. Cronin, "Plasmon resonant enhancement of dye sensitized solar cells," Energy and Environmental Science, vol. 4, no. 11, pp. 4650-4655, 2011.

[48] J. Qi, X. Dang, P. T. Hammond, and A. M. Belcher, "Highly efficient plasmon-enhanced dye-sensitized solar cells through metal@oxide core-shell nanostructure," ACS Nano, vol. 5, no. 9, pp. 7108-7116, 2011.

[49] D. Zhang, M. Wang, A. G. Brolo, J. Shen, X. Li, and S. Huang, "Enhanced performance of dye-sensitized solar cells using gold nanoparticles modified fluorine tin oxide electrodes," Journal of Physics D, vol. 46, no. 2, Article ID 024005, 2013.

[50] S. W. Sheehan, H. Noh, G. W. Brudvig, H. Cao, and C. A. Schmuttenmaer, "Plasmonic enhancement of dye-sensitized solar cells using core-shell-shell nanostructures," The Journal of Physical Chemistry C, vol. 117, no. 2, pp. 927-934, 2013.

[51] Y. Liu, H. Zhai, F. Guo et al., "Synergistic effect of surface plasmon resonance and constructed hierarchical $\mathrm{TiO}_{2}$ spheres for dye-sensitized solar cells," Nanoscale, vol. 4, no. 21, pp. 68636869, 2012.

[52] Q. Xu, F. Liu, W. Meng, and Y. Huang, "Plasmonic core-shell metal-organic nanoparticles enhanced dye-sensitized solar cells," Optics Express, vol. 20, no. 23, pp. A898-A907, 2012.

[53] H. Choi, W. T. Chen, and P. V. Kamat, "Know thy nano neighbor. Plasmonic versus electron charging effects of metal nanoparticles in dye-sensitized solar cells," ACS Nano, vol. 6, no. 5, pp. 4418-4427, 2012.

[54] S. Muduli, O. Game, V. Dhas et al., " $\mathrm{TiO}_{2}-\mathrm{Au}$ plasmonic nanocomposite for enhanced dye-sensitized solar cell (DSSC) performance," Solar Energy, vol. 86, no. 5, pp. 1428-1434, 2012.

[55] M. D. Brown, T. Suteewong, R. S. S. Kumar et al., "Plasmonic dye-sensitized solar cells using core-shell metal-insulator nanoparticles," Nano Letters, vol. 11, no. 2, pp. 438-445, 2011.

[56] C. Nahm, H. Choi, J. Kim et al., "The effects of $100 \mathrm{~nm}$-diameter Au nanoparticles on dye-sensitized solar cells," Applied Physics Letters, vol. 99, no. 25, Article ID 253107, 2011.

[57] V. P. Zhdanov, "On the use of metal nanoparticles for enhancement of light absorption in dye-sensitized solar cells," Physica E, vol. 43, no. 1, pp. 494-497, 2010. 
[58] C. Thanachayanont, C. Photiphitak, P. Rakkwamsuk, P. Muthitamongkol, and C. Sae-Kung, "Effect of silver nanoparticle size on efficiency enhancement of dye-sensitized solar cells," International Journal of Photoenergy, vol. 2011, Article ID 258635, 8 pages, 2011.

[59] L. Yuan, F. Chen, C. Zheng, J. Liu, and N. Alemu, "Parasitic absorption effect of metal nanoparticles in the dye-sensitized solar cells," Physica Status Solidi A, vol. 209, no. 7, pp. 1376-1379, 2012.

[60] S. Chang, Q. Li, X. Xiao, K. Young Wong, and T. Chen, "Enhancement of low energy sunlight harvesting in dye-sensitized solar cells using plasmonic gold nanorods," Energy \& Environmental Science, vol. 5, no. 11, pp. 9444-9448, 2012.

[61] U. Opara Krašovec, M. Berginc, M. Hočevar, and M. Topič, "Unique $\mathrm{TiO}_{2}$ paste for high efficiency dye-sensitized solar cells," Solar Energy Materials and Solar Cells, vol. 93, no. 3, pp. 379-381, 2009. 

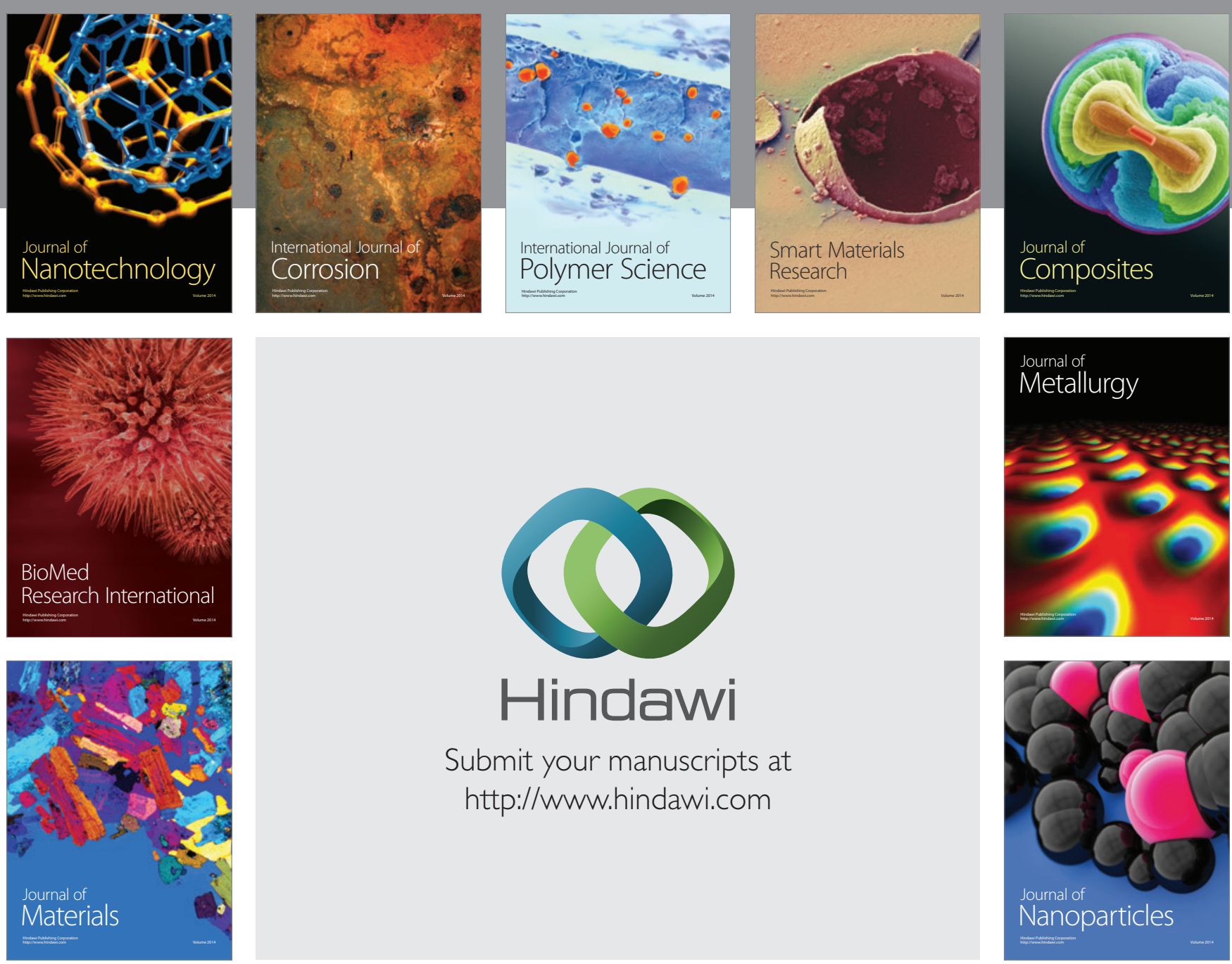

Submit your manuscripts at http://www.hindawi.com
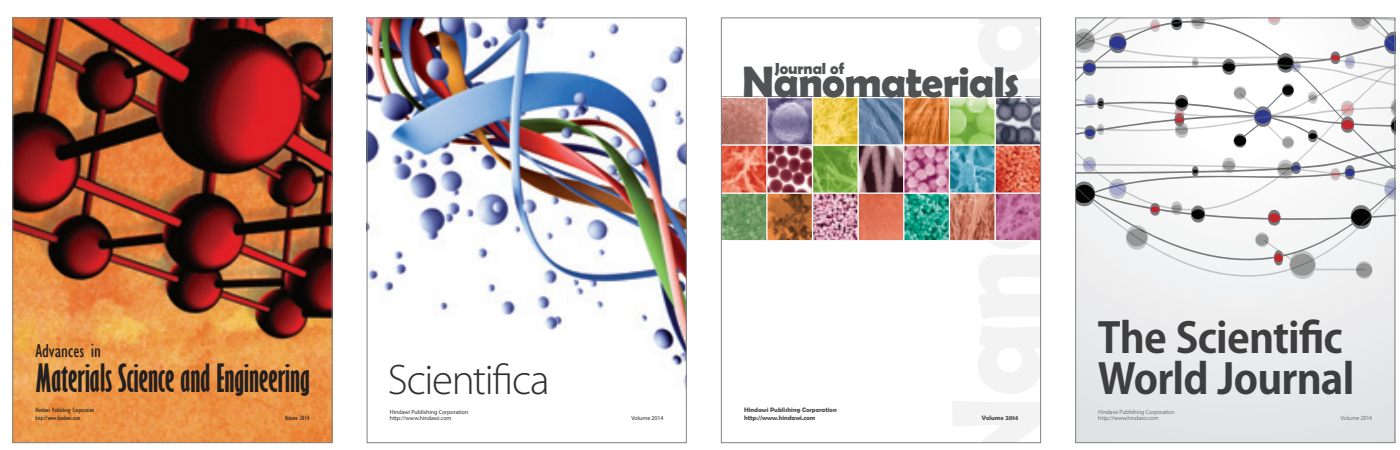

\section{The Scientific World Journal}
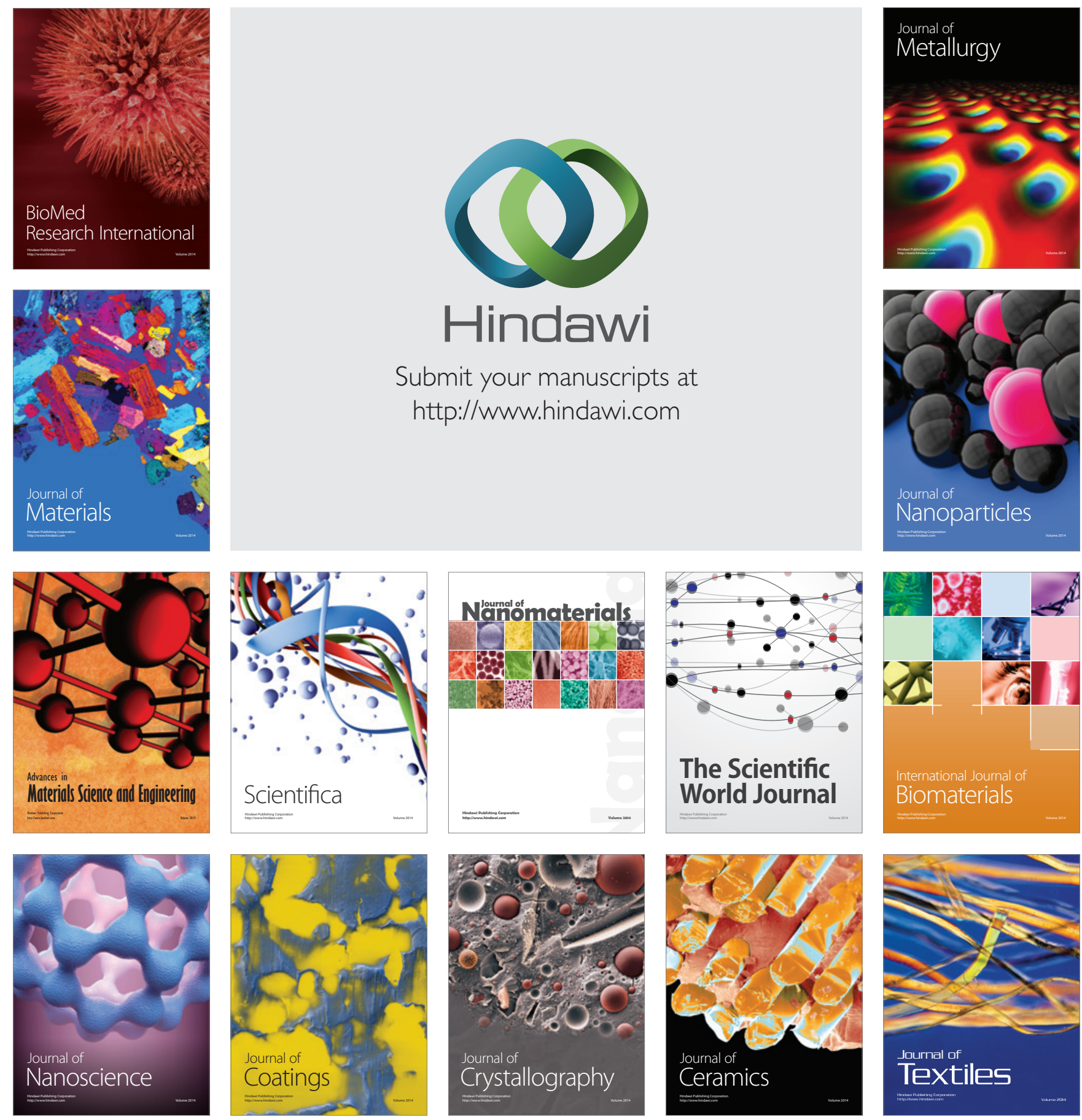